\title{
Environmental Information Disclosure Quality and Equity Financing Cost
}

\author{
Liping $\mathrm{Su}^{1,}$, , Huimin Zhang ${ }^{2,}$, , \\ ${ }^{1,2}$ School of Economics \& Management \\ Inner Mongolia University of Science \& Technology \\ Baotou, Inner Mongolia P.R., China \\ aslp_nmbt@126.com, b961806189@qq.com \\ ${ }^{*}$ Corresponding author
}

Keywords: Environmental information disclosure quality, Equity financing Cost, industry

\begin{abstract}
This paper selects the key stocks of A-shares in Shanghai stock market in 2016-2018 as a research sample, and analyzes the relationship between the quality of environmental information disclosure and the cost of equity financing. Considering that key polluting enterprises are subordinate to different industries, they focus on key polluting enterprises. The industry analyzed the differences in the impact of environmental information disclosure quality on equity financing costs. The research shows that there is a significant negative correlation between the quality of environmental information disclosure and the cost of equity financing. For different industries, the sensitivity of environmental information disclosure quality to equity financing costs varies due to differences in industry nature.Finally, based on the empirical conclusions and the actual situation of China's Shanghai A-share key pollutant discharge enterprises, the company itself and investors put forward corresponding countermeasures and suggestions.
\end{abstract}

\section{Introduction}

In recent years, corporate environmental problems are not uncommon. In order to encourage enterprises to actively assume environmental management responsibilities, China has successively introduced a number of laws and regulations requiring enterprises to enhance environmental governance and reduce pollution emissions. For key polluting enterprises, adopt mandatory environmental governance and encouragement environment. The way of information disclosure is to supervise and manage environmental issues: For example, the contents and format of the Information Disclosure Contents and Formats of Companies That Offer Securities to the Public No. 2, published in December 2017, the contents and format of the annual report (revised in 2017), as stipulated in Article 44, The company or its important subsidiaries announced by the department shall disclose six major environmental information such as sewage discharge information and construction and operation of pollution prevention facilities in accordance with laws, regulations and departmental regulations.

In addition, in the latest "Guidelines for the Governance of Listed Companies" promulgated by the China Securities Regulatory Commission in September 2018, Article 95 stipulates that listed companies should disclose environmental information and other relevant information in accordance with laws and regulations and the requirements of relevant departments. Is the cost of equity financing of enterprises affected by the quality of environmental information disclosure? Based on the different industries of the enterprise, is there any difference in the impact of the quality of corporate environmental information disclosure on its equity financing costs? These problems have become a research hot spot that scholars pay close attention to. Therefore, this paper uses empirical analysis methods to study the relationship between environmental information disclosure quality and equity financing costs, with a view to guiding enterprises to standardize environmental management and environmental information disclosure quality through research conclusions and countermeasures, and to provide a theoretical reference for the improvement of the environmental information disclosure system. 


\section{Theoretical analysis and research hypothesis}

The research between environmental information disclosure quality and equity financing cost originates from the research on the relationship between social responsibility information quality and equity financing cost. At present, scholars almost unanimously believe that enterprises with high quality of environmental information disclosure often have a better sense of social honor, and investors will look good to such enterprises, and believe that such enterprises will develop relatively better in the future; At the same time, it can effectively alleviate the information asymmetry between enterprises and investors, which is very beneficial for enterprises to obtain financing advantages in the capital market.

On the contrary, for enterprises with poor environmental information disclosure, investors will raise the expected rate of return accordingly to offset the risks brought by the poor quality of corporate environmental information disclosure, and the level of financing will not rise and fall.Based on this, the hypothesis is proposed:

H1:Significant negative correlation between environmental information disclosure quality and equity financing costs

\section{Study designs}

\subsection{Sample selection and data sources}

This paper selects 356 key emitters of A-shares in China's Shanghai stock market from 2016 to 2018 as a sample of research, excluding listed companies that were ST and * ST listed during the study period and listed companies that were incompletely disclosed in financial data. After screening, a total of 298 listed companies were obtained.

There are several ways to source data in this article: (1)Environmental information disclosure data is collected manually through publicly available materials such as social responsibility report, sustainable development report, environmental report, and company annual report; (2) The relevant corporate financial data and other data in this paper are from Guotai An and Wande database. Excel2016 software was used in the early data collation and processing, and stata15 was used for data processing in later empirical analysis.

\subsection{Selection and measurement of the major variables}

According to the research content of this paper and the current relevant research selection variables, the definitions and descriptions of the main variables are shown in Table 1.

Table 1. Selection and measurement of the major variables.

\begin{tabular}{|c|c|c|c|}
\hline Variable types & Variable name & Symbol & Measurement \\
\hline explained variable & Equity financing cost & $\mathrm{R}$ & $R=\sqrt{\left(E P S_{2}-E P S_{1}\right) / P_{0}}$ \\
\hline $\begin{array}{l}\text { explanatory } \\
\text { variable }\end{array}$ & $\begin{array}{l}\text { Environmental information } \\
\text { disclosure quality }\end{array}$ & EDI & the sum of the scores \\
\hline \multirow{9}{*}{ control variable } & asset-liability ratio & LEV & total liabilities/total assets \\
\hline & corporate performance & $\mathrm{ROE}$ & $\begin{array}{l}\text { net profit/ average balance of } \\
\text { shareholders' equity }\end{array}$ \\
\hline & Company Size & Size & Natural logarithm of total assets \\
\hline & Equity nature & State & State-owned holding is 1 , otherwise 0 \\
\hline & Board size & Bsize & Natural logarithm of the number of board members \\
\hline & $\begin{array}{l}\text { Ratio of independent } \\
\text { directors } \\
\end{array}$ & Pctind & $\begin{array}{c}\begin{array}{c}\text { Number of independent directors / number of board } \\
\text { members }\end{array} \\
\end{array}$ \\
\hline & Business growth & MB & $\begin{array}{l}\text { Year-to-end ratio of total market capitalization/net assets } \\
\text { of the company }\end{array}$ \\
\hline & Year & YEAR & $\begin{array}{c}\text { The listed company belongs to } 1 \text { in the current year, } \\
\text { otherwise it is } 0 .\end{array}$ \\
\hline & Industry & Industry & $\begin{array}{c}\text { When the listed company belongs to the industry, it is } 1 \text {, } \\
\text { otherwise it is } 0 .\end{array}$ \\
\hline
\end{tabular}




\subsection{Regression models}

To verify Hypothesis 1 , this paper builds Model 1 .

$\mathrm{R}=\beta_{0}+\beta_{1} \mathrm{EDI}+\beta_{2} \mathrm{LEV}+\beta_{3} \mathrm{ROE}+\beta_{4} \mathrm{Size}+\beta_{5} \mathrm{State}+\beta_{6} \mathrm{Bsize}+\beta_{7}$ Pctind $+\beta_{8} \mathrm{MB}+\beta_{9}$ Year $+\beta_{10}$ Industry $+\varepsilon$ (Model 1)

\section{Empirical test and result analysis}

\subsection{Descriptive statistical analysis}

In Table 2, the maximum value of ED is 68 , the minimum value is 3, and the average value is 15.8949 , indicating that there is a large gap in the quality of environmental information disclosure between sample companies, and the quality of environmental information disclosure of key pollutant discharge enterprises is generally low; Mean of $\mathrm{R}$ is 0.1243 , the maximum value is 0.6659 , and the minimum value is 0.0164 . There is a big gap between the financing costs of sample companies.

Table 2 Descriptive statistics results table

\begin{tabular}{c|c|c|c|c|c}
\hline Variable & Obs & Mean & Std & Min & Max \\
\hline EDI & 894 & 15.8949 & 6.0117 & 3 & 68 \\
\hline R & 894 & 0.1243 & 0.0907 & 0.0164 & 0.6659 \\
\hline LEV & 894 & 0.4624 & 0.2066 & 0.0323 & 1.0809 \\
\hline ROE & 894 & 0.0791 & 0.1429 & -0.8594 & 1.3316 \\
\hline Size & 894 & 22.6545 & 1.4465 & 19.3323 & 27.0718 \\
\hline State & 894 & 0.6074 & 0.4886 & 0 & 1 \\
\hline Bsize & 894 & 3.0453 & 0.2423 & 2.3979 & 3.6889 \\
\hline Pctind & 894 & 0.1683 & 0.0413 & 0.75 & 0.3333 \\
\hline MB & 894 & 2.8829 & 2.1344 & 0.3574 & 13.9603 \\
\hline
\end{tabular}

In terms of control variables, mean of LEV is 0.4624 , which is within the normal range of $0.45-0.65$, but its maximum value is 1.0809 , which is too much outside the normal range, indicating that the financial risks of individual companies are higher; The maximum ROE of ROE is 1.3316, the minimum is -0.8594 , and the average is only 0.0791 , which indicates that the income of sample companies is generally low and the gap between different enterprises is large, and some enterprises have experienced serious losses.

\subsection{Correlation analysis}

Pearson correlation analysis was performed on the main variables of this paper. The results are shown in Table 3.It can be seen from Table 3 that the correlation coefficient between each variable is less than 0.5 , indicating that the choice of variables is reasonable and there is no serious Multiple collateral problem. The correlation coefficient between the quality of environmental information disclosure and the cost of equity financing is -0.147 , and it is significant at the $10 \%$ level, indicating a significant negative correlation between the two. Preliminary verification that hypothesis 1 is established.

Table 3 Pearson correlation coefficient table between variables

\begin{tabular}{c|c|c|c|c|c|c|c|c|c|c}
\hline & ED & R & PITI & LEV & ROE & Size & State & Bsize & Pctind & MB \\
\hline EDI & 1 & & & & & & & & & \\
\hline R & $-0.147^{*}$ & 1 & & & & & & & & \\
\hline PITI & $0.136^{* *}$ & $-0.128^{*}$ & 1 & & & & & & & \\
\hline LEV & $0.179^{* *}$ & $0.343^{* *}$ & -0.174 & 1 & & & & & & \\
\hline ROE & $0.068^{*}$ & $-0.363^{* *}$ & 0.064 & -0.234 & 1 & & & & & \\
\hline Size & $0.426^{* *}$ & $-0.052^{*}$ & $0.029^{* *}$ & 0.491 & $0.083^{*}$ & 1 & & & & \\
\hline State & $0.235^{* *}$ & $-0.096^{*}$ & -0.170 & 0.328 & -0.154 & 0.158 & 1 & & & \\
\hline Bsize & $0.151^{* *}$ & $-0.015^{* * *}$ & -0.071 & 0.207 & 0.056 & 0.354 & 0.362 & 1 & & \\
\hline Pctind & 0.017 & $0.006^{* *}$ & 0.015 & $-0.069^{*}$ & -0.041 & 0.026 & 0.026 & $-0.265^{* *}$ & 1 & \\
\hline MB & $0.018^{*}$ & 0.023 & $0.074^{*}$ & 0.107 & 0.109 & 0.531 & $0.283 *$ & 0.169 & -0.037 & 1 \\
\hline
\end{tabular}

Note: $* * *, * *$, and $*$ indicate significant at the $1 \%, 5 \%$, and $10 \%$ levels, respectively. 
In terms of control variables, the environmental information disclosure quality ED is significantly positively correlated with the asset-liability ratio LEV, company size Size, equity nature State, and board size Bsize.The equity financing cost $\mathrm{R}$ is significantly negatively correlated with the company size Size, the equity nature State, and the ROE ROE. The equity financing cost $\mathrm{R}$ is significantly positively correlated with the asset-liability ratio LEV.

\subsection{Regression analysis}

(1) Regression analysis of environmental information disclosure quality and equity financing cost

The results are shown in Table 4. The results show that the adjusted R2 is 0.218 , which is greater than 0.1 , indicating that the research data has a good fit with the model 1 , and the construction of the model 1 is reasonable. The regression coefficient of environmental information disclosure quality and equity financing cost is -0.0481 , and it is significant at $10 \%$ level, that is, The quality of environmental information disclosure of enterprises is negatively related to the cost of equity financing, further verifying the correctness of hypothesis 1.

Table 4 Regression Analysis of Disclosure Quality and Equity Financing Cost

\begin{tabular}{|c|c|c|}
\hline $\mathrm{R}$ & Coef. & T value \\
\hline EDI & $-0.0481^{*}$ & -1.86 \\
\hline LEV & $0.0425^{*}$ & 1.43 \\
\hline ROE & $-0.0374^{* *}$ & -0.81 \\
\hline Size & -0.0263 & 0.39 \\
\hline State & -0.00894 & -0.43 \\
\hline Bsize & -0.00264 & -1.76 \\
\hline Pctind & $0.00689^{* * *}$ & 2.14 \\
\hline MB & $0.0387^{* *}$ & 0.68 \\
\hline YEAR & \multicolumn{2}{|c|}{} \\
\hline N & \multicolumn{2}{|c|}{ control } \\
\hline Adj. R2 & 697 \\
\hline F value & \multicolumn{2}{|c|}{0.235} \\
\hline
\end{tabular}

(2) Differences in the impact of environmental information disclosure quality on equity financing costs among different industries

Because heavily polluting enterprises are subordinated to different industries, the different nature of corporate pollution determines the corresponding degree of environmental protection and social responsibility of enterprises in different industries. Therefore, this paper discusses the impact of environmental information disclosure on the difference of financing costs among heavily polluting enterprises.

Due to the limited number of sample companies, it does not meet the classification of 16 categories of heavily polluting industries. According to the classification of the industry by the CSRC, The sample companies are classified into six industries: extractive industry, pharmaceutical industry, chemical industry, food and beverage industry, electric power, metal and non-metal industry. As shown in Table 5. Multivariate regression was performed using Model 1, and the regression results are shown in Table 6.

Table 5 Industry Classification

\begin{tabular}{|c|c|c|}
\hline industry & Number of companies & Proportion \\
\hline the metal and non-metal & 83 & $28 \%$ \\
\hline he food and beverage & 36 & $12 \%$ \\
\hline the chemical industry & 45 & $15 \%$ \\
\hline the pharmaceutical industry & 89 & $30 \%$ \\
\hline the electric power & 24 & $8 \%$ \\
\hline the extractive industry & 21 & $7 \%$ \\
\hline
\end{tabular}


Table 6 Regression Analysis of the Impact of Environmental Information Disclosure on Equity Financing Costs

\begin{tabular}{|c|c|c|}
\hline industry & & EDI \\
\hline \multirow{2}{*}{ the metal and non-metal } & Coef & $-0.071^{* * *}$ \\
\cline { 2 - 3 } & T value & -6.21 \\
\hline \multirow{2}{*}{ he food and beverage } & Coef & $-0.047^{* *}$ \\
\cline { 2 - 3 } & T value & 2.47 \\
\hline \multirow{2}{*}{ the chemical industry } & Coef & $-0.062^{* *}$ \\
\cline { 2 - 3 } & T value & 4.98 \\
\hline \multirow{2}{*}{ the pharmaceutical industry } & Coef & $-0.053^{* * *}$ \\
\cline { 2 - 3 } & T value & -3.51 \\
\hline \multirow{2}{*}{ the electric power } & Coef & $-0.13^{* *}$ \\
\cline { 2 - 3 } & T value & -3.24 \\
\hline the extractive industry & Coef & $-0.04 * *$ \\
\cline { 2 - 3 } & T value & -2.42 \\
\hline
\end{tabular}

The coefficient of environmental information disclosure quality and equity financing cost for different industries, the extractive industry is 0.04 , the electric power is 0.13 , the pharmaceutical industry is 0.053 , the chemical industry is 0.062 , the food and beverage is 0.047 , and the metal and non-metal is 0.071. Compared with other industries, the quality of environmental information disclosure in the electric power industry is more sensitive to the impact of equity financing costs.

\section{Conclusion}

According to the analysis and research of this paper, the research conclusions are as follows:

(1) The higher the quality of environmental information disclosure, the lower the cost of equity financing, that is, the quality of environmental information disclosure is significantly negatively correlated with the cost of equity financing.For enterprises with low environmental information disclosure, investors will think that the company has a large risk of information asymmetry and requires a higher return on investment; on the contrary, the financing cost is reduced.Therefore, enterprises should improve the quality of environmental information disclosure and make the information they disclose more comprehensive and more authentic.

(2) For different industries, due to the different industries of heavy polluting enterprises, different heavy polluting industries operate different business and characteristics, and have different dependence on environment and energy. Under the dual pressures of environmental protection policies and their own business development, The degree of disclosure of environmental information will be different. The sensitivity of environmental information disclosure to financing and cost varies according to the nature of the industry.

\section{References}

[1] Guthrie J. Cuganesan S, Ward L, Industry specific social and environmental reporting, the Australian Food and Beverage Industry,Accounting Forum, vol.32, pp. 1-15, 2014.

[2] CongY, Freedman M, Corporate Governance and Environmental Performance and Disclosures, Advances in Accounting, vol.27, pp. 223-232, 2014.

[3] Menguc B, Auh S, Ozanne L, The interactive effect of internal and external factors on a proactive environmental strategy and its influence on a firm's performance, Journal of Business Ethics, vol. 94, pp. 279-298, 2015.

[4] Aerts W, Cormier D, Media legitimacy and corporate environmental communication, Accounting Organizations and Society, vol.34, pp. 1-27, 2009.

[5] Clarkson P M, Li Y, Richardson G D, Revisiting the Relation between Environmental Performance and Environmental Disclosure: An Empirical Analysis, Accounting Organizations and Society, vol.33, pp.303-327, 2008. 
[6]BeckAC, Campbell D, Shrives P J, Content analysis in environmental reporting research: Enrichment and rehearsal of the method in a British-German context, The British Accounting Review,vol.42, pp. 207-222, 2010.

[7] Botosan C A, Plumlee M, A Re-Examination of Disclosure Level and the Expected Cost of Equity Capital, Journal of Accounting Research, vol. 40, pp. 21 40,2012.

[8] Hail L, Leuz C, International Differences In the Cost of Equity Capital: Do Legal Institutions and Securities Regulation Matter, Journal of Accounting Research, vol. 44, pp. 485-531, 2016.

[9] Francis , Disclosure Incentives and Effects on Cost of Capital Around the World,Accounting Review, vol. 4, pp. 1125-1162,2015.

[10]Clarkson P M, Fang X, Li Y, The Relevance of Environmental Disclosures: Are Such Disclosures Incrementally Informative? Journal of Accounting and Public Policy, vol. 32, pp. 410-431, 2013.

[11] Sharfman, M. and C. Fernando, Environmental Risk Management and the Cost of Capital, Strategic Management Journal, vol. 29, pp. 569-592,2008.

[12] Raf Orens, Walter Aerts, Denis Cormier Web Based Non-Financial Disclosure and Cost of Finance, Journal of Business Finance and Accounting, vol. 37,pp.1057-1093, 2014. 